\title{
Biology of Neoseiulus californicus feeding on two-spotted spider mite
}

\author{
Maicon Toldi * \\ Noeli Juarez Ferla \\ Catiane Dameda \\ Fernanda Majolo \\ Museu de Ciências Naturais, Centro Universitário Univates \\ Caixa Postal 155, CEP 95900-000, Lajeado - RS, Brasil \\ * Autor para correspondência \\ maicon.toldi@hotmail.com
}

Submetido em 31/05/2012

Aceito para publicação em 11/02/2013

\section{Resumo}

Biologia de Neoseiulus californicus alimentando-se de ácaro rajado. Tetranychus urticae (Koch) destaca-se por ser um ácaro polífago. Em morangueiro, esse ácaro desenvolve-se na face inferior das folhas, causando lesão significativa. Este estudo teve por objetivo conhecer as características biológicas de Neoseiulus californicus (McGregor), proveniente de plantas de morangueiro cultivado. O estudo iniciou-se com trinta ovos individualizados em arenas com diferentes estágios de T. urticae como alimento. A duração média de ovo-adulto foi maior para fêmeas $(5,69 \pm 0.08)$ do que para machos $(5,35 \pm 0.11)$. A razão sexual foi de 0,66 e capacidade inata de aumento $(\mathrm{rm})$ foi de 0,15 fêmea/fêmea/dia. A taxa líquida de reprodução $\left(\mathrm{R}_{\mathrm{o}}\right)$ foi 17,10 vezes/geração, com uma média a cada geração (T) de 19,35 dias. Maior oviposição foi observada no $11^{\circ}$ dia após o seu início, com 2,7 ovos/fêmea/dia e a média foi de 38,14 $\pm 5,58$ ovos/fêmea. A razão finita de aumento $(\lambda)$ foi 1,41 fêmea/ dia. Neoseiulus californicus mostrou reproduzir-se adequadamente quando alimentado com T. urticae.

Palavras-chave: Controle biológico; Fragaria sp.; Inimigo natural; Tabela de vida; Tetranychus urticae

\section{Abstract}

Tetranychus urticae (Koch) stands out as a polyphagous mite. In a strawberry plant, this mite develops on the underside of leaves, causing a significant injury. This study aimed to know the biological characteristics of Neoseiulus californicus (McGregor), from cultivated strawberry plants. The study started with thirty eggs isolated in arenas with different stages of $T$. urticae. The average length of egg-adult was higher for females (5.69 \pm 0.08$)$ than for males $(5.35 \pm 0.11)$. The sex ratio was 0.66 and the innate capacity for increase (rm) was 0.15 female/ female/day. The net reproductive rate $\left(\mathrm{R}_{\mathrm{o}}\right)$ was 17.10 times/generation, with an average to each generation $(\mathrm{T})$ of 19.35 days. Greater oviposition was observed at the $11^{\text {th }}$ day after its onset, with 2.7 eggs/female/day and the average was $38.14 \pm 5.58$ eggs/female. The finite increase rate $(\lambda)$ was $1.41 \mathrm{female} /$ day. Neoseiulus californicus showed to reproduce properly when feeding on T. urticae.

Key words: Biological control; Fragaria sp.; Life table; Natural enemy; Tetranychus urticae 


\section{Introduction}

Using natural enemies to control mites is a reality in many countries. There're biofactories which create natural enemies and sell them to farmers, mainly in Europe and North America (MORAES, 2002). However, applied biological control isn't widely used because predators don't always adapt to the environment of the region where they're released (ESCUDERO; FERRAGUT, 2005). Thus, it's important that the natural enemy is adapted to climate conditions, has high predation capacity, and a high rate of population growth (WEINTRAUB; PALEVSK, 2008).

In many cultures, Tetranychidae stand out as organisms which reach a pest level in agroecosystems. Tetranychus urticae (Koch) has a large number of hosts to which it causes significant damages (MORAES; FLECHTMANN, 2008). In strawberry plants, this mite attacks mainly the underside of leaves, causing the formation of bleached spots, abundant web, and significant production loss (FERLA et al., 2007). Its populations are larger and more frequent within the fructification period. In conventional agriculture, control is commonly done using acaricides, which require a waiting period for fruit harvest.

The phytoseiid are predatory mites which control phytophagous mites, nematodes, fungi, and insects (ZHANG, 1963). Monteiro (2002) proposed to increase the biological control of Panonychus ulmi (Koch) in apple tree; a control strategy was proposed having phytoseiids Neoseiulus californicus in a greenhouse as a basis, on successive inoculative releases and using acaricides, in a commercial apple orchard in Vacaria, Rio Grande do Sul, Brazil. Greco et al. (2005) observed that the predator Neoseiulus californicus (McGregor) was effective for controlling T. urticae under laboratory conditions. In the state of Rio Grande do Sul, Brazil, two species of predatory mites stand out as natural enemies of $T$. urticae on strawberry plants: $N$. californicus and Phytoseiulus macropilis Banks (FERLA et al., 2007). These species have shown potential for control, but Ferla et al. (2011) point out that P. macropilis present a low functional response in the presence of low populations of prey. Thus, this predator has a difficulty for remaining in the environment for long periods, due to fluctuations of prey population. The same doesn't occur with $N$. californicus, which is a generalist predator using alternative food sources (MCMURTRY; CROFT, 1997). According to these authors, N. californicus is able to survive when the population density of its main prey is low, feed on other species, or even perform cannibalism. Escudero and Ferragut (2005) reported this predator feeding on Tetranychus turkestani Ugarov and Nikolski, Tetranychus ludeni Zacher, and Tetranychus evansi Baker \& Pritchard. It also feeds on Thrips tabaci Lindeman (Thripidae) (RAHMAN et al., 2009).

The predator $N$. californicus has a low reproductive capacity when compared to species of the Phytoseiulus genus. However, according to Gotoh et al. (2004), $N$. californicus may be more effective than Phytoseiulus species to control T. urticae with an average temperature above $25^{\circ} \mathrm{C}$. Lebdi-Grissa et al. (2005) also showed a $N$. californicus viability rate higher at $30^{\circ} \mathrm{C}$ than at $24^{\circ} \mathrm{C}$.

The use of alternative food source and the ability to resist to higher temperatures than other species allow $N$. californicus to remain for a longer period in the environment by preemptively acting. Mites may have a great genetic variability and its species specialize in environments where they remain for a long time (MAGALHÃES et al., 2007). Before introducing commercial some $N$. californicus strain in the region, it's important to understand its biological and ecological characteristics. Having this in mind, this study aims to understand the biological characteristics of a $N$. californicus strain from the strawberry plant in Cai Valley, when fed with T. urticae under laboratory conditions.

\section{Material and Methods}

This study was carried out at the acarology laboratory of Unidade Integrada Vale do Taquari de Ensino Superior (UNIVATES), Lajeado, Rio Grande do Sul, Brazil. The predator $N$. californicus was collected from strawberry plant leaves in the town of Feliz, Rio Grande do Sul, Brazil, at a commercial production site, and kept in laboratory feeding on T. urticae, cattail pollen (Typha angustifolia L.), and bean plant leaves (Phaseolus vulgaris L.) for two months before starting the study. 
The rearing stocks were conducted in chamber with $28 \pm 1^{\circ} \mathrm{C}$ in the photophase of 12 hours and $22 \pm 1^{\circ} \mathrm{C}$ in the scotophase and relative humidity of $70 \pm 5 \%$. The predatory mites were reared on bean plant leaves kept on moist sponges within plastic trays surrounded by distilled water. The arenas were covered with a glass plate, in order to maintain a high relative humidity.

In the biology study, arenas with $6 \mathrm{~cm}$ diameter and $1.5 \mathrm{~cm}$ depth were used at the center of a sponge circle with $4 \mathrm{~cm}$ diameter and $1 \mathrm{~cm}$ thick surrounded by water. On this sponge, a bean plant leave circle was added for about four days. Cola Biostop ${ }^{\circledR}$ was put on the edge of the leaves to prevent the predatory mites from escaping.

In each arena, 15 specimens at different stages of $T$. urticae were added as food source and, after 4 hours, 3 female $N$. californicus were added. These females were removed 6 hours after the introduction from 30 arenas, being kept just a mite egg/arena. The study started with a total of 30 eggs.

Three daily observations were made: 8:00 a.m., 1:30 p.m., and 7:00 p.m.; then, the life stages duration of the mites were checked. In the adult phase, females were kept mated with males obtained from rearing stock and the evaluations were performed once a day, at 1:30 p.m., in order to check the number of eggs laid and the survival rate. The eggs laid were collected and transferred to other arenas to determine the sex ratio of F1. The data obtained were compared through Student test at a 5\% significance level, using the BioEstat 5.0 software.

The data obtained in this study were organized for life table calculations (SILVEIRA et al., 1976), and, then, the values regarding net reproductive rate
$\left(\mathrm{R}_{\mathrm{o}}=\Sigma \mathrm{mx} .1 \mathrm{x}-\mathrm{mx}\right.$ : total eggs/females number; $1 \mathrm{x}$ : specimens alive/specimens total), average length of a generation $(\mathrm{T}=\mathrm{mx} .1 \mathrm{x} . \mathrm{x} / \mathrm{mx} .1 \mathrm{x} \Sigma)$, innate capacity for increase ( $\mathrm{rm}=\log \mathrm{Ro} / \mathrm{T} .0 .4343)$, and finite increase rate $(\lambda=$ antilog $\mathrm{rm})$ were calculated.

\section{Results and Discussion}

The $N$. californicus strain showed that T. urticae constitutes a suitable prey, since most specimens survived to the adult phase, laying eggs. The values obtained in this study were similar to those of other studies addressing this predatory species $(\mathrm{GOTOH}$ et al., 2004; ESCUDERO; FERRAGUT, 2005; LEBDIGRISSA et al., 2005).

The egg-adult average duration was higher for females $(5.69 \pm 0.08)$ than for males $(5.35 \pm 0.11)$ (Table 1). Lebdi-Grissa et al. (2005) also showed a significant difference between the developmental phases of eggadult for females and males of the same species, being lower for males at the temperatures of 24,30 , and $35^{\circ} \mathrm{C}$. However, Gotoh et al. (2004), at $25^{\circ} \mathrm{C}$, didn't observe a significant difference. The total viability of egg-adult was $96.67 \%$. Gotoh et al (2004) also found viability about $96 \%$ in a commercial strain, at $25^{\circ} \mathrm{C}$, while Escudero and Ferragut (2005) obtained a 93\% viability with a native strain from Valencia, Spain.

The fecundity average was $38.14 \pm 5.58 \mathrm{eggs} /$ female (Table 2). This value was lower than that of Gotoh et al. (2004) and Escudero and Ferragut (2005), who obtained $41.6 \pm 2.06$ and $57.78 \pm 8.96$ eggs/female, respectively. In turn, Lebdi-Grissa et al. (2005) observed lower fertility, with 30.7 and 35.2 eggs/female at 24 and $30^{\circ} \mathrm{C}$, respectively.

TABLE 1: Duration of immature stages of Neoseiulus californicus (in days $\pm \mathrm{SE}$ ) feeding on various stages of Tetranychus urticae at $28 \pm 1^{\circ} \mathrm{C}$ in the photophase of 12 hours and $22 \pm 1^{\circ} \mathrm{C}$ in the scotophase and relative humidity of $70 \pm 5 \%$.

\begin{tabular}{lcccccc}
\hline & & \multicolumn{5}{c}{ Immature stages } \\
\cline { 3 - 6 } & N* & Egg & Larva & Protonymph & Deutonymph & Egg-adult \\
\hline Viability (\%) & 30 & 100 & 96.67 & 100 & 100 & 96.67 \\
Females & 22 & $2.42 \pm 0.06 \mathrm{a}^{* *}$ & $0.73 \pm 0.04 \mathrm{a}$ & $1.60 \pm 0.09 \mathrm{a}$ & $0.94 \pm 0,08 \mathrm{a}$ & $5.69 \pm 0,08 \mathrm{a}$ \\
Males & 7 & $2.57 \pm 0.11 \mathrm{a}$ & $0.75 \pm 0.07 \mathrm{a}$ & $1.33 \pm 0.10 \mathrm{a}$ & $0.69 \pm 0.15 \mathrm{a}$ & $5.35 \pm 0.11 \mathrm{~b}$ \\
\hline
\end{tabular}

* Number of mites evaluated. ** Mean value followed by the same letter in the column don't differ statistically through Student test at a $5 \%$ significance level. 
TABLE 2: Average fecundity and duration ( \pm SE) of the preoviposition, oviposition, and postoviposition periods and longevity of male and female Neoseiulus californicus feeding on various stages of Tetranychus urticae, at $28 \pm 1{ }^{\circ} \mathrm{C}$ in the photophase of 12 hours and $22 \pm 1^{\circ} \mathrm{C}$ in the scotophase and relative humidity of $70 \pm 5 \%$.

\begin{tabular}{lcc}
\hline & $\mathbf{N} *$ & Mean \\
\hline Fecundity & 15 & $38.14 \pm 5.58$ \\
Pre-oviposition & 15 & $3.72 \pm 0.48$ \\
Oviposition & 15 & $15.87 \pm 2.33$ \\
Post-oviposition & 4 & $12.00 \pm 1.41$ \\
Female longevity & 22 & $20.00 \pm 2.57 \mathrm{~b} * *$ \\
Male longevity & 7 & $27.00 \pm 8.53 \mathrm{a}$ \\
\hline
\end{tabular}

$* \mathrm{~N}=$ number of mites evaluated. ** Mean value followed by the same letter in the column don't differ statistically through Student test at a 5\% significance level.

The duration of the pre-oviposition, oviposition, and post-oviposition periods were $3.72 \pm 0.48,15.87 \pm 2.33$, and $12.00 \pm 1.41$, respectively (Table 2 ). The oviposition period was lower than that observed by Gotoh et al. (2004) and Escudero and Ferragut (2005). A higher number of postures was observed at the $11^{\text {th }}$ day after the oviposition onset, with 2.7 eggs/female/day (Figure 1).
The net reproductive rate $\left(\mathrm{R}_{\mathrm{o}}\right)$ was 17.1 times per generation (Table 3), with an average duration of each generation (T) of 19.35 days. Gotoh et al. (2004) and Escudero and Ferragut (2005) found higher values for net reproductive rate, but a lower average length of generation.

The sex ratio found in this study was 0.66 and the innate capacity for increase (rm) was 0.15 female/ female/day. Gotoh et al. (2004) and Escudero and Ferragut (2005) found 0.27 and 0.28 female/female/ day, respectively. Perhaps, the smallest value obtained in this study was influenced by the increased average duration of each generation and the lowest sex ratio. The finite increase rate $(\lambda)$ was 1.41 females/day, i.e. the population increase would be of 1.41 time per day. The highest population increase was between $8^{\text {th }}$ and $11^{\text {th }}$ days (Figure 2).

However, further field studies are needed to prove the ability of $N$. californicus to control T. urticae and there's a lack of studies to determine the quantities of predators required to keep populations of $T$. urticae below the damage level.

FIGURE 1: Oviposition rate (eggs/female/day) of Neoseiulus californicus feeding on various stages of Tetranychus urticae, at $28 \pm 1^{\circ} \mathrm{C}$ in the photophase of 12 hours and $22 \pm 1^{\circ} \mathrm{C}$ in the scotophase and relative humidity of $70 \pm 5 \%$.

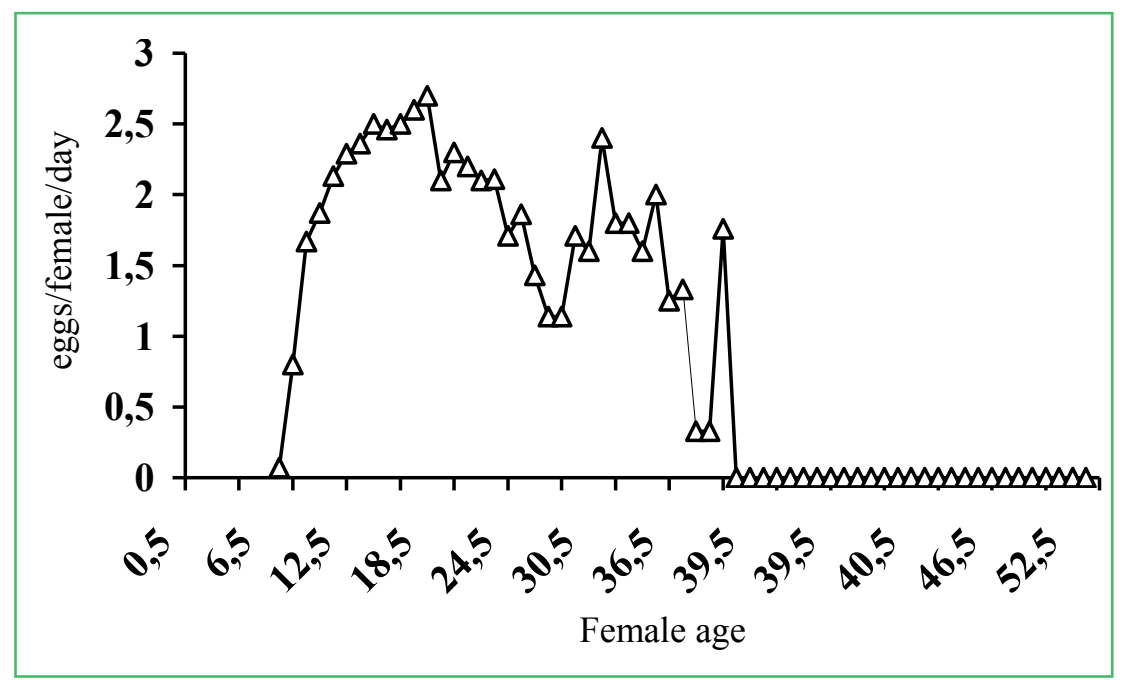


TABLE 3: Life table of Neoseiulus californicus feeding on various stages of Tetranychus urticae at $28 \pm 1{ }^{\circ} \mathrm{C}$ in the photophase of 12 hours and $22 \pm 1^{\circ} \mathrm{C}$ in the scotophase and relative humidity of $70 \pm 5 \%$.

\begin{tabular}{|c|c|c|c|c|c|c|}
\hline x (days) & eggs & females & $\mathbf{m x}$ & lx & mx.lx & mx.lx.x \\
\hline 0.5 & - & - & - & - & - & - \\
\hline 1.5 & - & - & - & - & - & - \\
\hline 2.5 & - & - & - & - & - & - \\
\hline 3.5 & - & - & - & - & - & - \\
\hline 4.5 & - & - & - & - & - & - \\
\hline 5.5 & - & - & - & - & - & - \\
\hline 6.5 & - & - & - & - & - & - \\
\hline 7.5 & 1 & 15 & 0.04 & 0.83 & 0.04 & 0.28 \\
\hline 8.5 & 12 & 15 & 0.53 & 0.73 & 0.39 & 3.29 \\
\hline 9.5 & 25 & 15 & 1.10 & 0.67 & 0.73 & 6.97 \\
\hline 10.5 & 28 & 15 & 1.23 & 0.67 & 0.82 & 8.62 \\
\hline 11.5 & 32 & 15 & 1.41 & 0.67 & 0.94 & 10.79 \\
\hline 12.5 & 32 & 14 & 1.51 & 0.63 & 0.96 & 11.94 \\
\hline 13.5 & 33 & 14 & 1.56 & 0.63 & 0.99 & 13.30 \\
\hline 14.5 & 35 & 14 & 1.65 & 0.63 & 1.05 & 15.15 \\
\hline 15.5 & 32 & 13 & 1.62 & 0.60 & 0.97 & 15.11 \\
\hline 16.5 & 25 & 10 & 1.65 & 0.50 & 0.83 & 13.61 \\
\hline 17.5 & 26 & 10 & 1.72 & 0.50 & 0.86 & 15.02 \\
\hline 18.5 & 27 & 10 & 1.78 & 0.50 & 0.89 & 16.48 \\
\hline 19.5 & 21 & 10 & 1.39 & 0.50 & 0.69 & 13.51 \\
\hline 20.5 & 23 & 10 & 1.52 & 0.50 & 0.76 & 15.56 \\
\hline 21.5 & 22 & 10 & 1.45 & 0.50 & 0.73 & 15.61 \\
\hline 22.5 & 21 & 10 & 1.39 & 0.50 & 0.69 & 15.59 \\
\hline 23.5 & 19 & 9 & 1.39 & 0.47 & 0.65 & 15.28 \\
\hline 24.5 & 12 & 7 & 1.13 & 0.40 & 0.45 & 11.09 \\
\hline 25.5 & 13 & 7 & 1.23 & 0.37 & 0.45 & 11.46 \\
\hline 26.5 & 10 & 7 & 0.94 & 0.37 & 0.35 & 9.16 \\
\hline 27.5 & 8 & 7 & 0.75 & 0.33 & 0.25 & 6,91 \\
\hline 28.5 & 8 & 7 & 0.75 & 0.30 & 0.23 & 6.45 \\
\hline 29.5 & 12 & 7 & 1.13 & 0.30 & 0.34 & 10.01 \\
\hline 30.5 & 8 & 5 & 1.06 & 0.23 & 0.25 & 7.52 \\
\hline 31.5 & 12 & 5 & 1.58 & 0.23 & 0.37 & 11.64 \\
\hline 325 & 9 & 5 & 1.19 & 0.23 & 0.28 & 9.01 \\
\hline 33.5 & 9 & 5 & 1.19 & 0.23 & 0.28 & 9.29 \\
\hline 34.5 & 8 & 5 & 1.06 & 0.23 & 0.25 & 8.50 \\
\hline 35.5 & 8 & 4 & 1.32 & 0.20 & 0.26 & 9.37 \\
\hline 36.5 & 5 & 4 & 0.83 & 0.20 & 0.17 & 6.02 \\
\hline 375 & 4 & 3 & 0.88 & 0.17 & 0.15 & 5.50 \\
\hline 38.5 & 1 & 3 & 0.22 & 0.17 & 0.04 & 1.41 \\
\hline 39.5 & 1 & 3 & 0.22 & 0.17 & 0.04 & 1.45 \\
\hline ) & 542 & & 38.41 & 14.17 & 17.1 & 330.92 \\
\hline
\end{tabular}


FIGURE 2: Specific fertility $(\mathrm{mx})$ and specific survival (1x) of Neoseiulus californicus feeding on various stages of Tetranychus urticae at $28 \pm 1^{\circ} \mathrm{C}$ in the photophase of 12 hours and $22 \pm 1^{\circ} \mathrm{C}$ in the scotophase and relative humidity of $70 \pm 5 \%$.

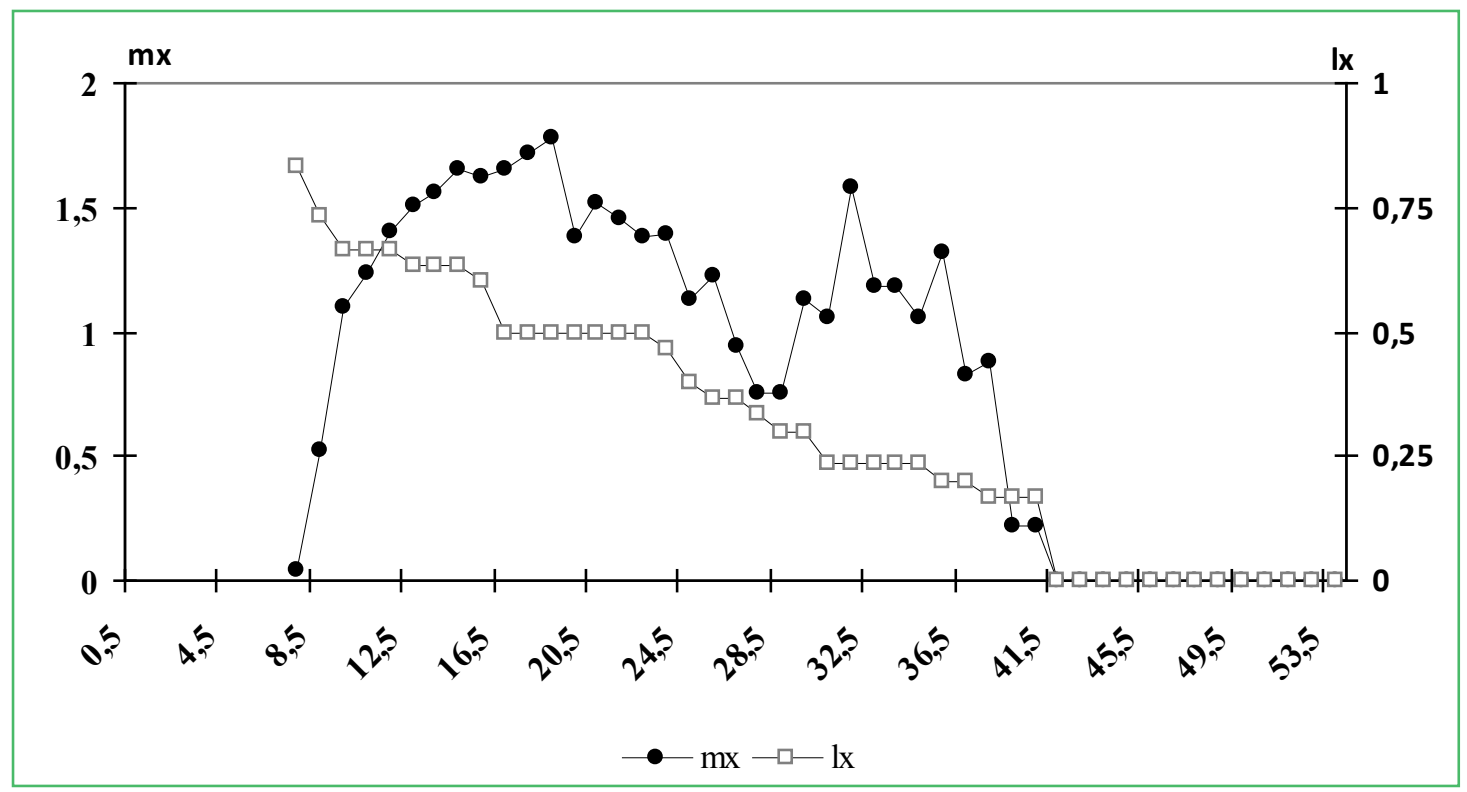

This study concludes that the $N$. californicus strain complete its life cycle in an adequate way feeding exclusively on $T$. urticae under laboratory conditions.

\section{Acknowledgments}

The authors thank to UNIVATES for research support; the Foundation for Research Support of the State of Rio Grande do Sul (FAPERGS) - Case 0905433 - for financial support; the National Council for Scientific and Technological Development (CNPq) for the scientific initiation scholarship; and the anonymous reviewers, for their comments and suggestions regarding the manuscript.

\section{References}

ESCUDERO, L. A.; FERRAGUT, F. Life-history of predatory mites Neoseiulus californicus and Phytoseiulus persimilis (Acari: Phytoseiidae) on four spider mite species as prey, with special reference to Tetranychus evansi (Acari: Tetranychidae). Biological Control, Cambridge, v. 32, p. 378-384, 2005.

FERLA, N. J.; MARCHETTI, M. M.; GONCALVES, D. Ácaros predadores (Acari) associados à cultura do morango (Fragaria sp., Rosaceae) e plantas próximas no Estado do Rio Grande do Sul. Biota Neotropica, Campinas, v. 7, n. 2, p. 103-110, 2007.
FERLA, N. J.; MARCHETTI, M. M.; JOHANN, L.; HAETINGER, C. Functional response of Phytoseiulus macropilis under different Tetranychus urticae (Acari: Phytoseiidae, Tetranychidae) population density in laboratory. Zoologia, Curitiba, n. 28, p. 1722, 2011.

GOTOH, T.; YAMAGUCHI, K.; MOR, K. Effect of temperature on life history of the predatory mite Amblyseius (Neoseiulus) californicus (Acari: Phytoseiidae). Experimental and Applied Acarology, Amsterdam, v. 32, p. 15-30, 2004.

GRECO, N. M.; SÁNCHEZ, N. E.; LILJESTHÖM, G. G. Neoseiulus californicus (Acari: Phytoseiidae) as a potential control agent of Tetranychus urticae (Acari: Tetranychidae): effect of pest/ predator ratio on pest abundance on strawberry. Experimental and Applied Acarology, Amsterdam, v. 37, p. 57-66, 2005.

LEBDI-GRISSA, K.; VANINPE, G.; LEBRUN, P. Paramètres biologiques et démographiques de Neoseiulus californicus (Acari: Phytoseiidae) à différentes températures. Acarologia, Paris, v. 1, p. 13-22, 2005.

MAGALHÃES, S.; FORBES, M. R.; SKORACKA, A.; OSAKABE, M.; CHEVILLON, C.; MCCOY, K. D. Host race formation in the Acari. Experimental and Applied Acarology, Amsterdam, p. 42, p. 225-238, 2007.

MCMURTRY, J. A.; CROFT, B. A. Life-styles of phytoseiid mites and their roles in biological control. Annual Review of Entomology, Palo Alto, v. 42, p. 291-321, 1997.

MONTEIRO, L. B. Manejo integrado de pragas em macieira no Rio Grande do Sul II: uso de Neoseiulus californicus para o controle de Panonychus ulmi. Revista Brasileira de Fruticultura, Jaboticabal, v. 24, p. 395-405, 2002.

MORAES, G. J. de. Controle biológico de ácaros fitófacos com ácaros predadores. In: PARRA, J. P. R.; BOTELHO, P. S. M.; CORRÊA-FERREIRA, B. S.; BENTO, J. M. S. (Ed.). Controle biológico no Brasil. São Paulo: Manole, 2002. p. 225-238. 
MORAES, G. J. de.; FlEChtMANN, C. H. W. Manual de acarologia: acarologia básica e ácaros de plantas cultivadas no Brasil. Ribeirão Preto: Holos, 2008. 308 p.

RAHMANI, H.; FATHIPOUR, Y.; KAMALI, K. Life history and population growth parameters of Neoseiulus californicus (Acari: Phytoseiidae) fed on Thrips tabaci (Thysanoptera: Thripidae) in laboratory conditions. Systematic \& Applied Acarology, Canberra, v. 14, p. 91-100, 2009.

SILVEIRA, S. N.; NAKANO, O.; BARBIN, D.; NOVA, A. V. Manual de ecologia e dos insetos. São Paulo: Agronomia Ceres, 1976. 419 p.

WEINTRAUB, P.; PALEVSKY, E. Evaluation of the predatory mite, Neoseiulus californicus, for spider mite control on greenhouse eweet pepper under hot arid field conditions. Experimental and Applied Acarology, Amsterdam, v. 45, p. 29-37, 2008.

ZHANG, Z. Mites of Greenhouses: identification, biology and control. Wallingford: Cabi Publishing, 1963. 244 p. 